vietims whose names will never be made public but who have purted with their money for this worthless device?

\section{"SCARE" METHOIN}

Like all medienl fakes, the sale for this is stimulated by attempts to frighten the susceptible. The dangers and frerueney of strangulation in hernin nre harped on throughout the advertising matter and hair-raising pietures of people in deadly peril are used to play still more on the feurs of those suffering from rupture. In one of the circulars there is a faked reproluction of an envelope sent out by the Stuart concer'n stul returmed to it with the inseription "Returned to writer: Bead" stumped on it.

\section{PIVATE AND CONFIDENTIA}

One more point commected with this encern and we are through. The following statements appear in the advertising matter sent out by the plaster pad company:

"lhe utmost pilvacy is alwhy molntained in all our correspond eller and bustuess redullons

"No one bered hesitule to wella us fully and completely regarding there ense, do nll leflors aro hold in strictest confidence."

In spite of this statement, we fiml alvertised for sale by one of the largest letter brokers in the comtry, listed under "Rupture Iettors" no fewer than 17.500 letters of the Stuart Plaster Pud Company. Privacy inderd!

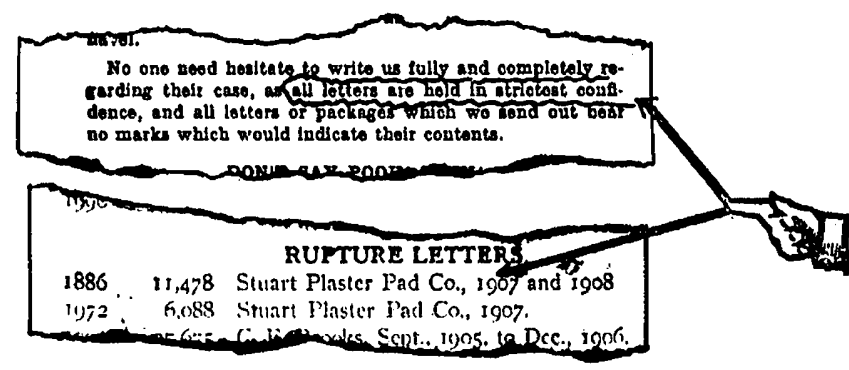

Jig. 3.--l'hotograplile reproductions (1) of sluart's advertising moltey, where the askertion is made that "nll letters are held in

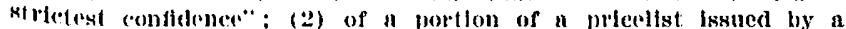
flem that malis's a bustnoss of buylng and selling letters that have

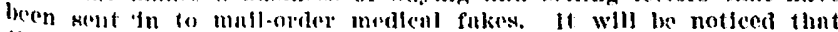
thls fhrm has more than 17,000 stunrt linster l'nd Co.'s letters por knlo. Comblentlal, ludeed

To sum up, we linve in the Pnpao Iaborntories, The., n concern thint promises to cure rupture by menns of a piece of anliesive planter and a little ointment. The dovice is exploited both directly to the public by newspmpers and indireetly to the public through the instrumentality of medical journals and of phypicinus who will sell the numes of sufferers of hernia for the price of a cheap thermomoter. Purchusers are obtained throngh fake anulyses and misleading testimonials. Finally, individinals who have been unwise enongh to answer Stuarts advertisements or who have been unfortumate enough to lave their mumes sent in by "local physician, lave had their mumes sold to letter brokie's to be bought by any person, anywhere, who is willing to pay the few cents necessury to obtain them.

A Testimonial.- The following letter was recoived by a maker of liniment at Carmine, Tex., aceosding to the Chiengo Tribune: "Mrs. Hattio louis say's lier sister have ben sick O weaks and 5 doetors treated her but fail to do her any good then whe went to the horke pittle and the doctors claim there they could not rench her ense. She wer swelling so she could not lie down. Sle would linfter be prop up in bed and could barly sit down and slie says the first time slie was trented with your liniment sle folt $n$ change nind now she are doing fhe and the swelling are all gone and she are able to do nll the conking in 0 days time which her mother had gave her 11) to clie."

\section{Correspondence}

\section{Precocious Children.}

T'o the Editor:-In Tule Jot:knat, Jan. 27, p. 27. I note an editorial on precocious ehildren as jutged by Professor (OShed in a recent issue of Seicnce. As Profossor o'Shear takes the liberty of speaking of my little daughter, Winifred Sackville Stoner, Jr., ns an example of a precocions elilal, 1 consider it my duty to Winifred as well as to other children to reply to the professor's arguments.

As a great lover of children and an enemy to the present system of public school training, which I believe makes boy and girl automatons, I have been earnestly stulying chili. training for the past ten years. From these observations. I camot agree with Professor o'shen that precocious ehildren do not observe people and Nuture as much as children untrained in book knowledge. What are good books but store houses of knowledge gathered by great minds after lon' periods of resenth on various subjects? Children who are trained to love these best of friends from babyliod will love them through life and thus huve friends that will never desert tliem. Besides, I linve noticed, contrary to l'rofessor O'shea's observations, that children who read books telling of Nature's realms find much more enjoyment in looking nt her works than those who see ler beanties through untrained eyes.

While taking a party of children throngh a beantiful wool last summer, I condd not help noticing, with pride, how much more enjoyment Winifred got out of leer walk thun the other children who knew nothing of the lenves, roots, ete., of the various trees. Everything added to one's storelsouse of knowl. edge, even in babylood, is mopen sesame to many pleasures. As a mere baby, Winifred found far more pleasure in wnlking along the sen shore and talking of the formations of shell, than the ordinary child who saw the shells us an oxtrich sees them-simply because of their brightness.

I ngree with Professor O'Shen in belicving that elikdren of 2 years who ean rend Milton, do not know the sense of whit they are rending. In studying the ordinary child truined by modern public school reading methods. I huve often found this to be true of children up to the age of 14 . Mnny of these children are nlso poor spellers. Recently in a test given in the New York high schools out of 1,000 pupils 800 could not spell the simplest words correctly. This is the result of sounding words which have no meming to a child's car.

Winifred, I nm ghad to say, was not taught by this method. She knew how to spell ench word and understood its meaning when she used it in reading, the true thought conveyor. She could read when less than 2 years of age, but not Milton. ller first reading book was the simple childish elnssic. "Peter Rubbit," which the child thoroughly understool and enjoyed.

J)espite the belief of many literary people that Winifed is a genius, 1 do not wish to see her so elussed. There is a narrow line between the genius and the fool. Many times tlie so-anlled genius is a lopsided erenture who shines in one direetion, but knows nothing of the great joys derived from a genernl knowledge of life.

Winifred, who at the age of 1 years can express lier thoughts in a number of languages, has pmblished three books and can talk intelligently on mythology, liternture, history, geomraphy, art, ete, is only a simple child who loves her playmates and dolls as mueh as her books. She delights in romping with ehildren of her own uge, but if left alone she is never lonely beeanse she las her book-friends or her store of knowledge to carry her to new worlds. She is as full of energy as a race liorse, but this energy las heen directed into proper clamels and does not work havoc as is often the ense witl children bubbling over with life. Early training through play has made the pathway of knowledge one of joy to Winifred It has ulso given her great powers of coneentration and obsorvation. With these two seeds implanted early in any child's mind, l. believe that child will succed in some partionlar line. Every child luns a talent. It is the duty of parent. to discover this talent and nourish it so that it will benr gool f:uit. 
As Winifred early alowed a love of verse, I have striven to drvelop this love by lending her to the storehonses of great poets. Slie lins never been compelled to study, but secks knowledge only when she is limugry for it. 'l'herefore her brain is never taxed, for it is only when interest flags that one is injured in thinking.

This child is such a happy, healthy voungster, who finds so much enjoyment in exploring realms very often luted by chil. dren, but which she ealls lier good gituts Mutematiko and (ieografio, that I yearn to see all children finding the patlos to knowledge us veritable pluygroumds.

lor the sake of our elhildren to whom we owe everything (having brought them into the world withont their asking) let me plead with parents not to take the ndvice of a few professors who believe in allowilig ehildren to grow as weeds until the sixth or eighth year. "As the twig bendeth so the tree groweth." One eannot begin too early in truining the rhild's mind, which, like wax, is very impressionable. Wo should teach our baby beantiful thoughts while he is yet in the cradle. Farly impressions are lasting. The old man for. gets things which he learned in the strength of his manhood, but when the evening of life creeps upon him he goes back to the thoughts of his youth. Then, how griteful will he be for the storehonse of wealth you have given him.

Wintrred Sackvild: S'ronfl, Pitlaburgh, Pan.

\section{The Management of Normal Labor.}

To the Editor:-l whould feel that 1 had neglected my duty if 1 failed to comment on an article on this subject in Tue Tounsal, January 27 , p. 274 . I am sure, in the unin, that the treatment as laid down in this aticle does not coincide with the advice and teachings of those who are giving obstetrics more than a passing thonght. IIad the anthor but referred to any molern text-book on obstetrics, he wonld have discovered that there had been just us great alvunement in this line of medicine as in the other branches and that much of the advice given by him belongs to " period antedating antiseptic surgery. T am surprised that this article should nppear in The Jounsa of the Amerienn Medical Associntion, and more so that the article was given such a prominent position. It does not seem necessary that I should point out the orrors, beause they are plain to anyone keeping in tonch with modern medical liternture; and I am sure, hal the article been properly edited, it would not have appenred in our valuable journal.

C. W. P’umose, Chicago.

Tho the vditor.-The artirle on normul labor, in a recent issue, was very alear fund concisc, but in one respect it surprised me extremely.

The subject of rubber groves was omitted. A deseription of obstetric work withont mention of rubber gloves is rather startling. If the author does not approve of gloves, and has other means of preparing the hands, why does he not mention the fact? Or does lie take for granted that we all wear gloves, as a matter of course? Evidently not, as lie advises us to rupture the membranes with our finger-nails.

Surely boiling water is always to be had. Therefore there ran be no eusier and quieker way of climinating infection than using boiled gloves.

A clenr understanding on this subject would surely be valuable to the muny who were interested mul instrueted by the mentioned article. IV. C. Gayter, Suint louis.

To the Hditor:-The general chancter of THe Jounnat is so high that it comes to your renders as a shock to find un article in its columns so much behind the times, and so full of errors that it would be a disgrnee to a proprietury advertising sheet. Such a slock I experienced in rending the article on "The Management of Normal Tabor."

As a guide to the management of labor for the general practitioner it is incomplete, as it omits vory important directions and it gives advice quite contrary to all the modern teaching. Without going into a compreliensive criticism I shall mention only a few things.

Omissions: preparatory chema; satisfactory cleaning of the putiont; dressing of patient; external exinmination of patient; mensurement of pelvis; nse of gloves.

Objectionable Advice: frequent internal examination: push. ing cervix over the head; anointing the perineum and seizing placenta in the vagina; manual removal of placenta in fortyfive minntes.

Questionable Adviee: use of eluloroform instrad of ether; interference with cord aroma neck; delay thirty minutes in cutting cord; rontine use of ergot.

'The article is not " eredit to fun .Journat.

\section{S. Bacon. Chicago.}

To the Elliton:-The parody on obstetrie technic publishen in 'Tue Jotersa., dan. 27 , whs, no doubt, given to show how badly the thing could be done. It seems to me, however, that the mission of 'TuE locensl. would be better fuldilled by giv. ing a elenn-cut. modern technic which might serve as an example, ruther than one which pulls the average practitioner down to the level of the illiternte midwife.

Is it forgotten: 1. That the vulva is shaved and serubbet with sonp and water, as well as with an mutiseptic solution?

2. Thut rubber gloves and not petrolatum are used in the twentieth enutury?

3. That the kelly pad is not yet out of date?

4. That contimul munipulations during the second stage are not gooul practice?

5. That petrolntum on the perinemu is ubont as useful as a snowbull in-- - panama?

6. That the cut cord should immedintely be protected from infertion?

7. That the ened should not be pulled on when delivering the placenta?

8. That a prophylactic for ophihalmia neonatorum should be used?

0. That an ablominul binder is needed by the mother? [Our correspondent has overlooked the fact that this is mentioned in the article. Please do not make the article ont to be any worse thun it is.-Eos.]

If I am wrong in believing naepsis to be the sine gun non of obstetrie practice, and that the technic given in 'lane Jouknst. is $1 \mathrm{~s}$ poor a specimen as could well be devised by a modern medicnl journul, then the sooner I know it the better.

$$
\text { Arculbaid) E. Chack, M. 1)., New York. }
$$

To the Editor:-Jhere appenred an urticle in THE Joursat. dexcribing the conduct of a cuse of normul labor. which atvo. cated certain procedures to be prneticed by the attending physiciun. Some of them, if the concluct of a cuse of labor is to be regurded us a surgienl procedure, which it most certuinly is, are deserving of severe criticism. After sterilization of the lands the following is adroented on part of the pluysician: "Ilaving lubriented the index and middle-fingers of his right lund with some sterile lubriennt. such as petrolutum. thas physician inserts these fingers into the vagina and examines the cervix nteri to determine whether it is dilnted, whether the pains aflect the muscular flbers of the cervix, whot part of the elild is presenting, if the heml is presenting, to defermine if possible the position in which it lies, and whether any purt of the placenta is attuched to the lower segment of the uterus. Incidentally he lenrus also the condition of the perinemu, whether it is rigid, dilatuble or reluxed; of the vagina, whether it is moist or dry; of the polvic walls, whether they are broad or narrow."

Why anybody should advornte the smearing of the exum. ining finger, or finger's, with a mess of petrolatum, which is renfered sterilo only with grent diftienlty and is kept so with even mo'e trouble, is beyond comprehension. It is eertaiuly a reversion to nntiquated mothods of technic. Surely the finger's of " lanul covered with " sterile glove can be rendily made insertible by the application of sterile green. 